\title{
Employee Performance Optimization Through Transformational Leadership, Procedural Justice, and Training: The Role of Self-Efficacy*
}

\author{
G. KUSUMANINGRUM ${ }^{1}$, Siswoyo HARYONO ${ }^{2}$, Rr. Sri HANDARI ${ }^{3}$
}

Received: September 10, 2020 Revised: November 08, 2020 Accepted: November 16, 2020

\begin{abstract}
This study aims to analyze the effect of transformational leadership (TL), procedural justice (PJ), and training (T) on employee performance (EP) mediated by self-efficacy (SE). The object of this research is Rumah Sakit Umum Daerah (RSUD) M.Th. Djaman, a hospital in Sanggau Regency, while the subjects are the institution's staff. Data collection search uses purposive sampling with a total of 120 samples. Data are obtained through questionnaires distributed directly to respondents using the Google Form application. Data analysis techniques used in this study include standard error of mean (SEM) with AMOS software version 24.00. Methods use to test validity and reliability of data include Confirmatory Factor Analysis (CFA), Construct Reliability (CR) and VE. The results of the analysis show that only training has a significant effect on self-efficacy, and self-efficacy has a significant effect on employee performance. Also, self-efficacy is proven to mediate the role of training on employee performance; the other hypotheses are not significant. Training is the most prominent positive factor affecting self-efficacy and self-efficacy has a significant effect on employee performance at RSUD M.Th. Djaman. The results of this study can be used as a reference by management in determining what policy priorities should take precedence.
\end{abstract}

Keywords: Transformational Leadership, Procedural Justice, Training, Self-Efficacy, Employee Performance

JEL Classification Code: D20, D22, D23

\section{Introduction}

Employee performance relates to work performance, namely, by comparing between established standards and the

\footnotetext{
*Acknowledgments:

This article uses data collected from M.Th.Djaman Hospital, Sanggau District, West Kalimantan Province, Indonesia. The author would like to thank civil servants as respondents and hospital management for supporting this research.

${ }^{1}$ First Author and Corresponding Author. Magister Management Program, Postgraduate Studies, Universitas Muhammadiyah Yogyakarta, Indonesia [Postal Address: Jl. Brawijaya, Tamantirto, Kec. Kasihan, Bantul, Yogyakarta, 55183, Indonesia]

Email: kusuma.pasca18@mail.umy.ac.id

2Professor and Head, Doctoral Management Program, Postgraduate Studies, Universitas Muhammadiyah Yogyakarta, Indonesia. Email: profsiswoyo@umy.ac.id

${ }^{3}$ Lecturer, Doctoral Management Program, Postgraduate Studies, Universitas Muhammadiyah Yogyakarta, Indonesia.

Email: handari@umy.ac.id

(c) Copyright: The Author(s)

This is an Open Access article distributed under the terms of the Creative Commons Attribution Non-Commercial License (https://creativecommons.org/licenses/by-nc/4.0/) which permits unrestricted non-commercial use, distribution, and reproduction in any medium, provided the original work is properly cited.
ontestricted non-commerial
}

results achieved (Dessler \& Varrkey, 2005). Yang and Hwang (2014) also stated that employee performance is the outcome of work completed by staff that exceeds work standards within a predetermined period. Performance must be assessed or evaluated. Assessment of performance (performance appraisal) means to evaluate the performance of employees in the present or the past relative to the performance standards. Some experts say many factors affect employee performance. Diamantidis and Chatzoglou (2019) argue that the support provided by management and the environment of the workplace has a very strong impact on work performance, while direct job performance relates to adaptation factors and internal motivation. This research was conducted at the M.TH. Djaman Hospital, Sanggau Regency, West Kalimantan Province, which is a class $\mathrm{C}$ hospital, a regional referral hospital for several hospitals in the surrounding. The outcomes of the pre-research interview method with a few department heads, room heads, and hospital employees, revealed that employee performance was still not optimal. This condition can be seen from several employees who often arrive late to the office, are unable to complete their work on time according to the targets set, and complete the work awaiting the leadership's orders. Therefore, the leadership 
must attend to the performance of its employees, because if the employee's performance decreases it can affect the quality of hospital services.

The results of observations and sighting conducted with the head of the department and the head of the treatment room, revealed the problem of lack of management support facilitating training for employees to improve employee performance, and the lack of equal opportunity to receive training decided by the leadership. Routine evaluations that have been carried out internally indicate that not all employees have self-efficacy or abilities that refer to high individual trust in the ability to achieve success in executing the tasks assigned. Training is needed to improve service performance. When employees have good soft skills and hard skills, they can focus on work, can work together, can solve problems, and high motivation will automatically increase employee self-efficacy in completing work so that the vision and mission targeted by the hospital will be achieved.

According to theory and previous research on transformational leadership, procedural justice and training with a variety of indicators that were conducted separately can affect employee performance. Therefore, this study will explore efforts to improve employee performance through the construct of transformational leadership, procedural justice, and training with self-efficacy as a mediating variable. There are no empirical studies conducted using these three construct variables simultaneously mediated by self-efficacy to improve employee performance. The self-efficacy theory (Bandura, 1997) recognizes the capabilities and confident in people's abilities to complete the tasks given. Therefore, further research is needed to provide support for this theory.

\section{Literature Review and Hypothesis Development}

\subsection{Literature Review}

\subsubsection{The effect of Transformational Leadership (TE) on Self-Efficacy (SE)}

\section{Transformational leadership (TE)}

TL is a model of leadership to improve human resources and the relationship between leaders' effects on subordinates measured, with the existence of trust, admiration, loyalty, and respect for leaders, trying to motivate followers to do something more and go beyond their expectations (Bass \& Bass, 2008). A leader who can create a positive change in his subordinates is called transformational leadership. Such leaders focus on "transforming", always help each other, nurture one another, encourage and harmonize, and pay attention to the organization as a whole (Banks et al., 2016).

AbuBakar (2018) states that a leader is someone who is able to influence others to work with certain motivations.
Transformational leadership theory is demonstrated by the existence of a leader who uses a style that brings change; this theory produces an emotional bond between followers or employees and the leader. The magnitude of the influence of a leader on his subordinates can determine the quality of transformational leadership. Employees always give appreciation and trust that continues to increase in the leadership and they are also ready to manifest work behavior that exceeds the expectations of the leader (Geier, 2016).

\section{Self-Efficacy (SE)}

$\mathrm{SE}$ is a perspective theory formulated by Albert Bandura. SE refers to realized abilities, belief in one's own ability to succeed in completing a given task (Bandura, 1997). SE is different from self-confidence. The concept of SE was popularized in the 1980-1990 period, in Bandura's book, The Exercise of Control (1997), which explains that confidence or trust is a vague term that refers to the power of conviction, but does not specify the limits of certainty. Unlike the case with SE, which refers more to the target, is more targeted behavior toward an achievement. SE tends to the subject's gradual self-assessment of his ability to perform an action that must be done in solving a problem, while self - confidence indicates confidence in oneself about the resources he has, but is too broad. The effectiveness that focuses on creativity will contribute to offset the obstacles experienced.

Mittal and Dhar (2015) revealed that TL is significantly related to creativity that is mediated by creative SE. Transformational leadership is very important to boost employees to have confidence in completing their tasks and work. This is in line with a study by Afsar and Masood (2017) finding that, with the interaction between mediators, innovative work behavior is built positively and significantly by transformational leadership and self-efficacy. Walumbwa et al. (2005) said that TL with moderating SE role is proven to have a positive relationship with EP. Wang et al. (2014) also proved that SE is positively influenced by TL. If the leader has implemented transformational practices, the employee SE is getting better. Astuty and Udin (2020) found that TL has a significant effect on performance. Investigations by Azim et al. (2019) found TL significantly predicts the involvement of the creative process, and creative SE mediates in part the relationship of TL and the process of creative involvement. The results show that TL forms a conducive organizational climate for employee's creative SE by building employee SE.

\subsubsection{Procedural Justice (PJ) on Self-Efficacy (SE)}

Cropanzano et al. (2007) said that organizational justice is fair treatment obtained at work where such fair treatment 
can encourage increased cooperation in groups because it can understand the attitudes and behavior of fellow employees in the organization. PJ refers to accepted justice from the procedures used to make decisions (Cropanzano et al., 2007). According to Kinicki and Fugate (2015), procedural justice is justice used in making a decision through established processes and procedures. If the individual feels that the justice he has received is reasonable, then the individual can feel the PJ he has already obtained. Top and Tekingunduz (2018) argued that it is important to improve organizational fairness, which decrease work stress, especially among medical personnel in hospitals, and thus foster employees' trust for the organization.

$\mathrm{Tu}$ and $\mathrm{Lu}$ (2014) confirmed a moderated intervention model in which SE acts as a mediating factor between ethical leadership and EP. The results support the effects of ethical leadership on the performance of individual extra roles and the mediating role of overall SE. Zhang et al. (2015) said that, for staff that has low perceptions of PJ or taking risks, performance imbalances are negatively related to $\mathrm{SE}$ and creativity because there is a positive relationship between $\mathrm{PJ}$ or enthusiasm to take risks on SE and creativity. Janati (2017) found a significant relationship between organizational justice and SE because of the fact that organizational justice is known to greatly affect employee SE; managers must create strategies to increase SE through organizational justice for the performance of their employees.

PJ has a positive effect on the EP, so employees will make a greater contribution to the organization and have greater work motivation if fairness is in the form of policies and procedures (Thanh \& Toan, 2018). Schuh et al. (2017) argue that leaders' mindfulness is linked to central leadership behavior, that is, the extent to which leaders engage in procedures that are fair to their employees. The meaning of the perception of justice as a whole will strengthen positive defiance and performances in the workplace (Swalhi et al., 2017). Research conducted by Zahra et al. (2017) explores the direct and mediated impacts that make SE a potential mediator. The result shows that ethical leadership (EL) has a significant relationship with innovative work behavior. This shows that leadership ethics encourages innovative employee's work behavior beyond what is planned. In team justice, it also shows that, generally, team justice has a positive influence on individual SE, which in turn positively influences development in his workplace (Bensemmane et al., 2018).

\subsubsection{Effect of Training on Self-Efficacy (SE)}

Dessler and Varrkey (2005) say that training is a process of teaching the basic skills needed to carry out work by new or old employees. Training can be one way to improve the quality of human resources. New and old employees still need to attend training periodically because of the demands of work that keep changing along with the changing environment. Paragraph 9 of Law No.13 of 2003 concerning Labor states: "Job training is the overall activity to give, obtain, improve, and develop work competence, productivity, discipline, attitude, and work ethic at certain skill ranks and knowledge following the levels and qualifications of positions and occupations".

Other findings from Brooke et al. (2017) show that factors related to individuals (training and previous experience) have a significant influence on knowledgesharing behavior. These results also show that self-efficacy mediates between factors connected to individuals, social support, and knowledge-sharing behavior. Loomba and Karsten (2019) synthesize the SE literature pointing a role model of SE in influencing the successful execution of quality improvement programs in organizations. The better quality the training program provided to employees, the more SE the employees will have. Dang and Chou (2019) suggested that SE has a decisive role in employee success to understand a new culture. Training programs must encourage and emphasize employee's SE abilities. Such training can increase self-confidence and employee capability to be able to solve problems in unexpected circumstances.

\subsubsection{The Effect of Transformational Leadership (TL) on Employee Performance (EP)}

Fadila et al. (2018) said that TL affected the performance of nurses in PKU Muhammadiyah Gamping Hospital. Saleem et al. (2019) found that TL has a significant positive influence on the EP. Razak et al. (2018) suggested the application of a TL style in a company can affect the level of employee discipline, namely, the leadership style has a positive relationship with work discipline. Pancasila et al. (2020) prove that EP is significantly influenced by leadership. Other studies show that TL has a high enough effect on EP when compared to instrumental leadership even though this difference is very slight (Chammas \& Hernandez, 2019). EP is strongly influenced by leadership style also evidenced by Hermina and Yosepha (2019) in their research conducted at PT. Trakindo Utama Pontianak, The results showed that the TL style had a direct effect on EP. Furthermore, leadership style, work discipline, and work motivation have a significant influence on EP.

\subsubsection{Effect of Procedural Justice (PJ) on Employee Performance (EP)}

Schuh et al. (2017) presented a four-factor dimension model that matched the data and revealed that mindful 
leaders have positive and significant indirect effects on EP. According to Haerani et al. (2020) organizational justice received by employees will make employees more satisfied at work, display a good commitment to the organization, which in turn creates maximum performance for the organization. Swalhi et al. (2017) state that specific measurements of fairness have a positive effect on job performance. Research conducted by Kalay (2016) revealed that procedural justice affects EP. This is similar to evidence by Zeb et al. (2019) that revealed that organizational justice (distributive, procedural, interactional) positively correlated significantly with performance. According to Tjahjono et al. (2019), employee happiness is very much determined by the justice obtained in the organization, so that it will foster a balance between work and one's own happiness, while doing work. Fairness in this organization can certainly improve the work quality of the employees themselves.

\subsubsection{Effect of Training on Employee Performance (EP)}

Ugbomhe et al. (2016) explain that tailored training/ development has a significant relationship to job needs and staff motivation for higher performance in banks in Edo State. The same thing was stated by Ibrahim et al. (2017), who prove that a good training program and an increase in soft skills training will lead to improved performance and eventually organizational success. Nadeera and Islam (2018) found that training and development had a significant impact on EP. Taufek and Mustafa (2018) found that there was a significant influence between training design and EP. Otoo and Mishra (2018) say that some human resource development have an impact on employee training programs with a positive effect on EP in the workplace (Halawi \& Haydar, 2018).

\subsubsection{Effect of Self-efficacy on Employee Performance (EP)}

A longitudinal study conducted by Carter et al. (2018) found that SE has an effect on EP and this suggests that SE should be managed well together with employee interactions in increasing EP. Thundiyil et al. (2016) showed research aimed at testing a model that links the positive and negative influences of Chinese employees and creative SE on the creative performance of supervisors in Chinese business. The results show a positive effect of creative SE on employee creativity.

The same was stated by Singh et al. (2017), who shows the relationship between thinking self-leadership and SE and intervention mechanisms where SE influences positively and significant sales performance. Research by Black et al. (2019) also revealed that SE has a positive effect on the cohesiveness of a team; it was also found that there was a mediator role of high SE between emotional intelligence and team cohesiveness. High emotional intellect encourages the increase of SE, which results in improved team cohesiveness. Developed group cohesiveness results in better-quality performing and team involvement. The results of the study conducted by Afzal et al. (2019) also show that controller support is felt to influence EP through mediating SE.

\subsection{Hypotheses}

Based on some empirical evidence obtained from the previous studies, the authors develop the following hypotheses:

H1: TL influences the self-efficacy of employees at M.Th. Djaman Hospital.

H2: Procedural justice influences the self-efficacy of employees at M.Th.Djaman Hospital.

H3: Training influences employee self-efficacy in M.Th. Djaman Hospital.

H4: Transformational leadership influences employee performance in M.Th.Djaman Hospital

H5: Procedural justice influences the performance of employees in M.Th.Djaman Hospital

H6: Training influences employee performance at the M.Th.Djaman Hospital

H7: Self-efficacy influences employee performance in M.Th.Djaman Hospital

\section{Research Methods and Materials}

This type of study is a quantitative research that is a data group carried out using a research instrument in the form of a questionnaire. This research is a one-shoot or crosssectional study. Research Cross-sectional represents the research process is conducted by way of collecting data in one. The process can take place over days or weeks or months to be able to answer questions in research (Sekaran \& Bougie, 2016).

The place of research is RSUD M.Th. Djaman, Sanggau Regency, West Kalimantan. The object of the study was all employees of the State Civil Apparatus (ASN) at the M. Th Hospital. Djaman Sanggau Regency. This data collection search uses purposive sampling by distributing questionnaires to 120 samples using Google Form. Data were analyzed using SEM with the tools IBM SPSS and AMOS 24.0 0. Exogenous variables used in this research that transformational leadership, procedural justice, and training. While the endogenous variables used are SE and EP. The variable will be measured using a Likert scale on answers to scales 1 to 5 , from 1 "strongly disagree" to 5 "strongly agree". 


\section{Results and Discussion}

\subsection{Results}

Based on the test results of the Confirmatory Factor Analysis (CFA), five of the 25 indicators were invalid because they had a loading factor of $>0.5$, one indicator was invalid because it has a loading factor of $<0.5$. Reliability testing results were from Construct Reliability (CR) and VE.

From Table 1, with training and SE with a probability below $0.05, \mathrm{H} 0$ is not accepted and $\mathrm{H} 1$ is accepted; the statement $p$ value is $=0.029 \leq 0.05$. So, it shows that training has a significant influence on SE.

Table 1: Results of Reliability Test Constructions

\begin{tabular}{|l|c|c|c|}
\hline Variable & CR & VE & Information \\
\hline $\begin{array}{l}\text { Transformational } \\
\text { leadership }\end{array}$ & 0.99 & 0.64 & Reliable \\
\hline Procedural Justice & 0.87 & 0.57 & Reliable \\
\hline Training & 0.96 & 0.63 & Reliable \\
\hline Self-Efficacy & 0.96 & 0.83 & Reliable \\
\hline $\begin{array}{l}\text { Employee } \\
\text { performance }\end{array}$ & 0.92 & 0.75 & Reliable \\
\hline
\end{tabular}

Dessler and Varrkey (2005) say that training is a process of teaching the basic skills needed to carry out work by new or old employees. Training can be one way to improve the quality of human resources. New and existing employees still need to attend training periodically because of the changing job demands along with the changing work environment.

The general purpose of training is to develop skills, to be faster and more effective in completing a job, to develop knowledge, so that work can be completed rationally, and to develop attitudes that foster a willingness to work together among employees and with management (leaders). From the results of this data processing, the hypothesis proposed in this research is in line with the results of previous research by Stocks and Slater (2016), Brooke et al. (2017), Kerr et al. (2018), Loomba and Karsten (2019), and Dang and Chou (2019) that show a positive and significant relationship between training and SE. This is according to the SE theory proposed by Bandura (1997), which states that a person must learn various skills to diagnose their strengths and weaknesses to optimize the person's potential to increase SE.

P-value between SE on EP with a probability below 0.05 the value indicates that $\mathrm{H} 0$ is rejected and $\mathrm{H} 1$ is accepted; the statement $\mathrm{p}$ value is $=0.000 \leq 0.05$.

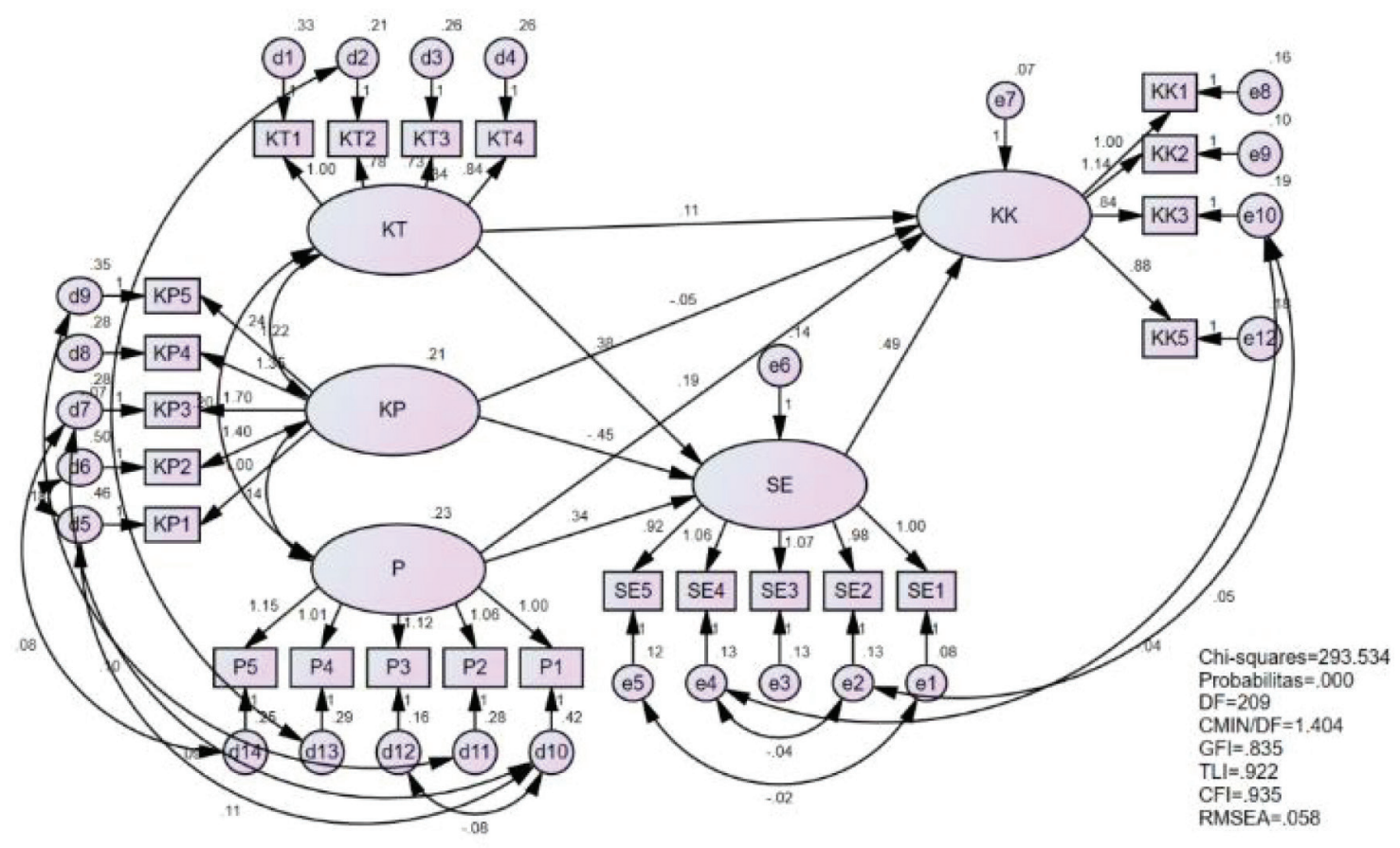

Figure 1: Fit the Research Model to the Method Structural Equation Model (SEM) 
This means that SE has a significant effect on the EP. Judging from the results from the respondents' answers, the statement "I will display an attitude that shows confidence in the entire work process" shows the highest value. This means that employees have committed themselves to be able to carry out their work that has a broad as well as specific range.

As per Bandura (1991), someone who has high SE will have better performance because he has strong motivation, clear goals, good emotional stability, enthusiasm, and the ability to produce optimal performance. However, if SE is very low, then an employee tends not to try for the maximum efforts. Bandura and Schunk (1989) suggest that SE is very important in driving motivation in each individual and in achieving predetermined performance. SE is a trust in one's capacity to perform tasks perfectly. A person will find it easier to achieve success if he has high SE, so that he will be more confident in his abilities, while people who have low self-efficacy always feel more likely to fail (Bandura, 1997). So that, when employee SE is high, it can optimize their performance.

The mediation effect that will be tested is the mediating role of the SE variable between the training variables and employees. The mediation effect that will be tested is the mediating role of the SE variable between the training variables and EP. The effect of the training variable on $\mathrm{SE}$ is 0.382 and the effect of SE on EP is 0.529. While the total effect of training on EP is greater with SE as a mediator $(0.226+0.202=0.428)$ than the direct effect of training on employee performance (0.226) and indirect influence $(0.202)$. This means that $\mathrm{SE}$ is proven to mediate training on EP.

Table 2: P-Value

\begin{tabular}{|l|c|c|c|c|}
\hline & & & P. & Information \\
\hline TL & $\rightarrow$ & SE & 0.158 & H1 not accepted \\
\hline $\mathrm{PJ}$ & $\rightarrow$ & SE & 0.136 & H1 not accepted \\
\hline $\mathrm{T}$ & $\rightarrow$ & SE & 0.029 & H1 accepted \\
\hline $\mathrm{TL}$ & $\rightarrow$ & EP & 0.631 & $\mathrm{H} 1$ not accepted \\
\hline $\mathrm{PJ}$ & $\rightarrow$ & EP & 0.837 & $\mathrm{H} 1$ not accepted \\
\hline $\mathrm{T}$ & $\rightarrow$ & EP & 0.146 & $\mathrm{H} 1$ not accepted \\
\hline $\mathrm{SE}$ & $\rightarrow$ & EP & 0.000 & $\mathrm{H} 1$ accepted \\
\hline
\end{tabular}

Table 3: Standardized Direct Effects

\begin{tabular}{|l|c|c|c|c|c|}
\hline & T & PJ & TL & SE & EP \\
\hline SE & .382 & -.483 & .521 & .000 & .000 \\
\hline EP & .226 & -.060 & .159 & .529 & .000 \\
\hline
\end{tabular}

Table 4: Standardized Indirect Effects

\begin{tabular}{|l|c|c|c|c|c|}
\hline & T & PJ & TL & SE & EP \\
\hline SE & .000 & .000 & .000 & .000 & .000 \\
\hline EP & .202 & -.256 & .276 & .000 & .000 \\
\hline
\end{tabular}

Table 5: Standardized Total Effects

\begin{tabular}{|l|c|c|c|c|c|}
\hline & T & PJ & TL & SE & EP \\
\hline SE & .382 & -.483 & .521 & .000 & .000 \\
\hline EP & .428 & -.316 & .435 & .529 & .000 \\
\hline
\end{tabular}

\subsection{Discussion}

The results of the study have implications for managerial policy. The results of this study can be used as a reference by management in determining what policy priority scale should take precedence. Training is the most dominant positive factor affecting self-efficacy significantly, and selfefficacy has a significant effect on employee performance at RSUD M.Th. Djaman.

Referring to the highest training indicator value is the statement "I found an instructor who mastered the material, delivered it clearly and was easy to understand". This means that the training needed by employees is training provided by competent sources and instructors who master the material/experts in their fields. Furthermore, if the training received comes from competent instructors, the employees as training participants will easily understand the training material presented. The types of training provided to employees must be following the job description of each employee. Employees are also given the right to apply for the training needed so that employees will be able to actively participate in the training; the process of understanding the material will be easier. The provision of training must also be well planned by the relevant department, be it training facilities, accommodation, and financial support during training. Training must be carried out periodically so that the development of employee's knowledge and technology is always updated to support employee performance in providing services to patients.

The dominant SE indicator value is in the statement "I will display an attitude that shows self-confidence in the entire work process". This indicates that employee self-efficacy is good enough. The individual is very confident in his ability to get work done. This situation makes employees continue to strive diligently to complete their assigned tasks using their abilities. Employees can motivate themselves to be able to choose and take the necessary actions in completing tasks. Thus, the employee can face obstacles and difficulties and the individual is always sure that any task can be completed properly. 
Overall, some of the things mentioned above can be interpreted as effects that arise after attending the training. With increased competence that continues to be developed through training, employee SE will increase. His ability to complete the job will have a greater chance of doing well. In line with this, it can be seen from the most dominant employee performance indicator value, namely, in the statement "I use my abilities (hard skills and soft skills) to complete work following established standard operating procedures (SOP)". This means that the quantity of work produced by employees has been carried out based on the standards and targets of each individual. Then, the work has been properly understood to be carried out with full responsibility and priority, and with a work plan that is under the procedure. Employees are also considered capable of building good team performance so that the target of completing work is within the specified time limit.

Management or related departments must create a database of training and development activities for all hospital employees so that the hospital resource development program is always controlled. Facilitated training must also be designed according to the needs of the hospital to be more effective and efficient. Meanwhile, management must also be able to stimulate, so that the training received can be applied to the work unit of the employee concerned; it can optimize the increase in self-efficacy so that it can simultaneously affect employee performance, both individual performance, and unit performance. According to Bandura (1991) someone who has high self-efficacy will have better performance because he has strong motivation, clear goals, good emotional stability, is passionate, and able to produce optimal performance. Carter et al. (2018) suggest that SE should be managed well together with employee interactions to increase EP. Based on the results of this study, the grand finding is that self-efficacy can increase along with the increase in training provided to employees. The increase in self-efficacy by employees can improve the performance of employees of RSUD M.Th. Djaman. Therefore, the relevant department in the hospital can set up training plans to increase employee self-efficacy in carrying out their work so that employee performance can be optimized.

\section{Conclusions}

After statistical analysis it was found that transformational leadership does not affect self-efficacy, procedural justice does not affect on self-efficacy, training has a significant effect on self-efficacy, transformational leadership does not affect employee performance, procedural justice does not affect employee performance, training does not affect employee performance, and self-efficacy has a significant effect on employee performance.

The higher the training, the higher the employee's self-efficacy, further optimizing employee performance because, when someone has a high value of self-efficacy, it will produce excellent performance, which is supported by high enthusiasm and clear goals. Future studies should find out how to develop variables to get better results by considering variables that can affect self-efficacy in addition to transformational leadership, procedural justice, and variables that affect employee performance.

Future research could also look at other variables that can affect the performance of employees such as motivation and organizational culture (Paais \& Pattiruhu, 2020) where the results show that employee performance has a higher tendency to be built on motivation, leadership, organizational culture and job satisfaction. An increased employee performance will be obtained along with increased job satisfaction, which is the result of motivation, leadership and organizational culture. Compensation and work motivation also greatly affect employee performance, as evidenced in research conducted by Sumiarti et al. (2018). Job involvement, perceived organizational support, and organizational culture where the results of the study, which found that employee performance was significantly influenced by job involvement, organizational culture, and perceptions of organizational support (Asria \& Amali, 2018). Haryono et al. (2020) also expressed the same view, by combining several other factors with training, namely, that promotion and work motivation had a significant effect on work performance, so the suggestion put forward was to design a routine training plan for employees. Besides, doing promotions together with training will increase work motivation, which in turn has an effect on increasing EP.

\section{References}

AbuBakar, A. (2018). Spiritual leadership and employee performance: mediating role of organizational commitment in Indonesian public university. Journal English Applied Science, 13(12), 4344-4352.

Afsar, B., \& Masood, M. (2017). Transformational Leadership, Creative Self-Efficacy, Trust in Supervisor, Uncertainty Avoidance, and Innovative Work Behavior of Nurses. The Journal of Applied Behavioral Science, 54(1), 36-61. https:// doi.org/10.1177/0021886317711891

Afzal, S., Arshad, M., Saleem, S., \& Farooq, O. (2019). The impact of perceived supervisor support on employees' turnover intention and task performance. Journal of Management Development, 38(5), 369-382. https://doi.org/10.1108/jmd-032019-0076

Asria, M., \& Amali, H. (2018). The Influence of Job Involvement, Perceptions Of Organizational Support, And Organizational Culture On Employee Performance At The Village Community Empowerment Office Of West Sumatera Province. European Journal of Business and Management, 10(34). 
Astuty, I., \& Udin, U. (2020). The Effect of Perceived Organizational Support and Transformational Leadership on Affective Commitment and Employee Performance. Journal of Asian Finance, Economics and Business, 7(10), 401-411. https://doi.org/10.13106/jafeb.2020.vo17.no10.401

Azim, M. T., Fan, L., Uddin, M. A., Jilan, M. M. A. K., \& Begum, S. (2019). Linking transformational leadership with employees' engagement in the creative process. Management Research Review, 42(7), 837-858. https://doi.org/10.1108/mrr-08-20180286

Bandura, A. (1991). Self Efficacy Mechanism in Psychological and Health-Promoting Behavior. Upper Saddle River, NJ: Prentice Hall.

Bandura A., \& Schunk, D. H. (1989). Cultivating competence, Selfefficacy, and intrinstic interest trough proximal self-motivation. Journal of Personality and Social Psychology, 41, 586-598. https://psycnet.apa.org/doi/10.1037/0022-3514.41.3.586

Bandura A. (1997). Self-efficacy: The exercise of control. New York, NY: W.H. Freeman and Company.

Banks, G. C., McCauley, K. D., et al. (2016). A meta-analytic review of authentic and transformational leadership: A test for redundancy. The Leadership Quarterly, 27(4), 634-652. doi:https://doi.org/10.1016/j.leaqua.2016.02.006

Bass, B. M., \& Bass, R. (2008). The Bass Handbook of Leadership: Theory, Research, and Managerial Applications. New York, NY: Free Press.

Bensemmane, S., Ohana, M., \& Stinglhamber, F. (2018). Team justice and thriving: a dynamic approach. Journal of Managerial Psychology, 33(2), 229-242. https://doi.org/10.1108/jmp-072017-0223

Black, J., Kim, K., Rhee, S., Wang, K., \& Sakchutchawan, S. (2019). Self-efficacy and emotional intelligence. Team Performance Management: An International Journal, 25(1/2), 100-119. https://doi.org/10.1108/tpm-01-2018-0005

Brooke, J., Mohd Rasdi, R., \& Samah, B. A. (2017). Modelling knowledge sharing behaviour using self-efficacy as a mediator. European Journal of Training and Development, 41(2), 144-159. https://doi.org/10.1108/ejtd-04-2016-0021

Carter, W. R., Nesbit, P. L., Badham, R. J., Parker, S. K., \& Sung, L. K. (2018). The effects of employee engagement and selfefficacy on job performance: a longitudinal field study. The International Journal of Human Resource Management, 29(17), 2483-2502. https://doi.org/10.1080/09585192.2016.1 244096

Chammas, C. B., \& Hernandez, J. M. D. C. (2019). Comparing transformational and instrumental leadership. Innovation \& Management Review, 16(2), 143-160. https://doi.org/10.1108/ inmr-08-2018-0064

Cropanzano, R., Bowen, D. E., \& Gilliland, S. W. (2007). The management of organizational justice. Academy of Management Perspectives, 21(4), 34-48.

Dang, V. T., \& Chou, Y.-C. (2019). Extrinsic motivation, workplace learning, employer trust, self-efficacy and cross-cultural adjustment. Personnel Review. https://doi.org/10.1108/pr-102018-0427

Dessler, G., \& Varrkey, B. (2005). Human Resource Management. Delhi, India: Pearson Education.

Diamantidis, A. D., \& Chatzoglou, P. (2019). Factors affecting employee performance: an empirical approach. International Journal of Productivity and Performance Management, 68(1), 171-193. https://doi.org/10.1108/IJPPM-01-2018-0012

Fadila, E., et al. (2018). Pengaruh Kepemimpinan Transformasional, Motivasi Kerja, dan Budaya Organisasi Terhadap Kinerja Perawat di RS PKU Muhammadiyah Gamping. Universitas Muhammadiyah Yogyakarta, Yogyakarta. Retrieved from http://repository.umy.ac.id/handle/123456789/22045

Geier,M.T.(2016).Leadershipin extremecontexts:Transformational leadership, performance beyond expectations? Journal of Leadership \& Organizational Studies, 23(3), 234-247. https:// doi.org/10.1177\%2F1548051815627359

Haerani, S., Sumardi, Hakim, W., Hartini, \& Putra, A. H. P. K. (2020). Structural Model of Developing Human Resources Performance: Empirical Study of Indonesia States Owned Enterprises. Journal of Asian Finance, Economics and Business, 7(3), 211-221. https://doi.org/10.13106/jafeb.2020. vol7.no3.211

Halawi, A., \& Haydar, N. (2018). Effects of Training on Employee Performance: A Case Study of Bonjus and Khatib \& Alami Companies. International Humanities Studies, 5(2), 24-45. Retrieved from https://www.researchgate.net/profile/Ali Halawi4/publication/325420167

Haryono, S., Supardi, S., \& Udin, U. (2020). The effect of training and job promotion on work motivation and its implications on job performance: Evidence from Indonesia. Management Science Letters, 10(9), 2107-2112. http://dx.doi.org/10.5267/j. msl.2020.1.019

Hermina, U. N., \& Yosepha, S. Y. (2019). The Model of Employee Performance. International Review of Management and Marketing, 9(3), 69-73. https://10.32479/irmm.8025

Ibrahim, R., Boerhannoeddin, A., \& Kayode, B. K. (2017). The effect of soft skills and training methodology on employee performance. European Journal of Training and Development, 41(4), 388-406. https://doi.org/10.1108/ejtd-08-2016-0066

Janati, A., Gholizadeh, M., Naseri, N., \& Ahmadi, Z. (2017). The Relationship between Organizational Justice Perception and Self- efficacy in Staff of a Selected Educational Hospital: a case study. Journal of Health Based Research. Retrieved from http://hbrj.kmu.ac.ir/article-1-171-en.html

Kalay, F. (2016). The Impact of Organizational Justice on Employee Performance: A Survey in Turkey and Turkish Context. International Journal of Human Resource Studies, 6(1). https:// doi.org/10.5296/ijhrs.v6il.8854

Kerr, S., Martin, C., \& Fleming, M. (2018). Preventing suicide; nurse education and the occluded issue of gender. Nurse Education in Practice, 32, 58-63. https://doi.org/10.1016/j. nepr.2018.07.004 
Kinicki, A., \& Fugate, M. (2015). Organizational Behavior: A Practical, Problem-Solving Approach. New York, NY: McGraw Hill.

Loomba, A. P. S., \& Karsten, R. (2019). Self-efficacy's role in success of quality training programmes. Industrial and Commercial Training, 51(1), 24-39. https://doi.org/10.1108/ ict-06-2018-0058

Mittal, S., \& Dhar, R. L. (2015). Transformational leadership and employee creativity. Management Decision, 53(5), 894-910. https://doi.org/10.1108/md-07-2014-0464

Nadeera, \& Islam, M. K. (2018). The Effects of Employee Engagement on Employee Performance in the Hotel Industry in Kelantan. Global Business and Management Research: An International Journal, 10(3), 828-838.

Otoo, F. N. K., \& Mishra, M. (2018). Measuring the impact of human resource development (HRD) practices on employee performance in small and medium scale enterprises. European Journal of Training and Development, 42(7/8), 517-534. https://doi.org/10.1108/ejtd-07-2017-0061

Paais, M., \& Pattiruhu, J. R. (2020). Effect of motivation, leadership, and organizational culture on satisfaction and employee performance. Journal of Asian Finance, Economics and Business, 7(8), 577-588. https://doi.org/10.13106/jafeb.2020. vol7.no8.577

Pancasila, I., Haryono, S., \& Sulistyo, B. A. (2020). Effects of work motivation and leadership toward work satisfaction and employee performance: Evidence from Indonesia. Journal of Asian Finance, Economics and Business, 7(6), 387-397. https://doi.org/10.13106/jafeb.2020.vol7.no6.387

Razak, A., Sarpan, S., \& Ramlan, R. (2018). Effect of Leadership Style, Motivation and Work Discipline on Employee Performance in PT. ABC Makassar. International Review of Management and Marketing, 8(6), 67-71. http://doi. org/10.32479/irmm.7167

Saleem, M. A., Bhutta, Z. M., Nauman, M., \& Zahra, S. (2019). Enhancing performance and commitment through leadership and empowerment. International Journal of Bank Marketing, 37(1), 303-322. https://doi.org/10.1108/ijbm-02-2018-0037

Schuh, S. C., Zheng, M. X., Xin, K. R., \& Fernandez, J. R. (2017). The Interpersonal Benefits of Leader Mindfulness: A Serial Mediation Model Linking Leader Mindfulness, Leader Procedural Justice Enactment, and Employee Exhaustion and Performance. Journal of Business Ethics, 156(4), 1007-1025. https://doi.org/10.1007/s10551-017-3610-7

Sekaran, U., \& Bougie, R. (2016). Research Model for Bussiness: A skill building approach ( $5^{\text {th }}$ ed.). New York, NY: John Wiley and Son Ltd.

Singh, R., Kumar, N., \& Puri, S. (2017). Thought self-leadership strategies and sales performance: integrating selling skills and adaptive selling behavior as missing links. Journal of Business \& Industrial Marketing, 32(5), 652-663. https://doi. org/10.1108/jbim-06-2016-0127
Stocks, G., \& Slater, S. (2016). Training in positive behavioural support: increasing staff self-efficacy and positive outcome expectations. Tizard Learning Disability Review, 21(2), 95-102. https://doi.org/10.1108/tldr-04-2015-0020

Sumiarti, T., Frinaldi, A., \& Syamsir, S. (2018). The Effect of Styles of Leadership, Compensation, and Motivation of Employees Civil Servant Performance in The General Hospital Pariaman. Paper presented at the ICSScE 2018.

Swalhi, A., Zgoulli, S., \& Hofaidhllaoui, M. (2017). The influence of organizational justice on job performance. Journal of Management Development, 36(4), 542-559. https://doi. org/10.1108/jmd-11-2015-0162

Taufek, F. H. M., \& Mustafa, M. (2018). The Effect of Training and Development towards Employee Performance: A Case Study in Proton Tanjung Malim. Global Business \& Management Research, 10(3), 777-781.

Thanh, V. B., \& Toan, N. V. (2018). The Relationship between Organizational Justice and Social Loafing in Ho Chi Minh City, Vietnam. Journal of Asian Finance, Economics and Business, 5(3), 179-183. http://doi.org/10.13106/jafeb.2018. vol5.no3.179

Thundiyil, T. G., Chiaburu, D. S., Li, N., \& Wagner, D. T. (2016). Joint effects of creative self-efficacy, positive and negative affect on creative performance. Chinese Management Studies, 10(4), 726-745. https://doi.org/10.1108/cms-06-2016-0126

Tjahjono, H. K., Fachrunnisa, O., \& Palupi, M. (2019). Configuration of organisational justice and social capital: their impact on satisfaction and commitment. International Journal of Business Excellence, 17(3), 336-360. https://doi. org/10.1504/IJBEX.2019.097957

Top, M., \& Tekingunduz, S. (2018). The Effect of Organizational Justice and Trust on Job Stress in Hospital Organizations. Department of Health Care Management, Faculty of Economics and Administrative Sciences Hacettepe University. https://doi. org/10.1111/jnu.12419

Tu, Y., \& Lu, X. (2014). Do Ethical Leaders Give Followers the Confidence to Go the Extra Mile? The Moderating Role of Intrinsic Motivation. Journal of Business Ethics, 135(1), 129-144. https://doi.org/10.1007/s10551-014-2463-6

Ugbomhe, U. O., Osagie, G. N., \& Egwu, E. U. (2016). Impact of Training and Development on Employee Performance in Selected Banks in Edo North Senatorial District. Nigeria. Indian Journal of Commerce \& Management Studies, 7(3), 48-55.

Walumbwa, F. O., Lawler, J. J., et al. (2005). Transformational leadership and work-related attitudes: The moderating effects of collective and self-efficacy across cultures. Journal of Leadership \& Organizational Studies, 11(3), 2-16. https://doi. org/10.1177\%2F107179190501100301

Wang, C.-J., Tsai, H.-T., \& Tsai, M. T. (2014). Linking transformational leadership and employee creativity in the hospitality industry: The influences of creative 
role identity, creative self-efficacy, and job complexity. Tourism Management, 40, 79-89. https://doi.org/10.1016/j. tourman.2013.05.008

Yang, C.-L., \& Hwang, M. (2014). Personality traits and simultaneous reciprocal influences between job performance and job satisfaction. Chinese Management Studies, 8(1), 6-26. https://doi.org/10.1108/CMS-09-2011-0079

Zahra, T. T., Ahmad, H. M., \& Waheed, A. (2017). Impact of Ethical Leadership on Innovative Work Behavior: Mediating
Role of Self-Efficacy. Journal of Behavioural Sciences, 27(1), 93-107.

Zeb,A.,Abdullah, N.H., Othayman, M.B., \&Ali, M. (2019). The Role of LMX in Explaining Relationships between Organizational Justice and Job Performance. Journal of Competitiveness, 11, 144-160. https://doi.org/10.7441/joc.2019.02.10

Zhang, Y., Long, L., \& Zhang, J. (2015). Pay for performance and employee creativity. Management Decision, 53(7), 1378-1397. https://doi.org/10.1108/md-11-2013-0596 